\author{
Uniwersytet Łódzki \\ Katedra Geografii Miast i Turyzmu \\ 90-142 Łódź, ul. Kopcińskiego 31 \\ tel. 048426354561 \\ jolwoj@geo.uni.lodz.pl
}

Jolanta Wojciechowska, Ewa Szafrańska, Tomasz Bużałek, Anna Lasek, Emilia Luczyńska, Karolina Lyżwa, Joanna Orzechowska

\section{STUDENCKIE ĆWICZENIA TERENOWE \\ W SANKT PETERSBURGU W 2006 R.}

\section{STUDENT FIELDWORK TRAINING IN ST PETERSBURG (2006)}

\section{WSTEP}

Zgodnie z umową o współpracy zawartą pomiędzy Uniwersytetem Łódzkim i Rosyjskim Państwowym Hydrometeorologicznym Uniwersytetem w Sankt Petersburgu, w dniach od 3 do 15 lipca 2006 r. studenci III roku geografii turyzmu i hotelarstwa wzięli udział w specjalizacyjnych ćwiczeniach terenowych w Federacji Rosyjskiej. Grupa składała się z pięciu studentów i dwóch pracowników Katedry Geografii Miast i Turyzmu. Ćwiczenia odbyły się już po raz czwarty, ponieważ współpraca naukowo-dydaktyczna obu uczelni rozpoczęła się w 2002 r., a coroczna wymiana studentów to jeden z jej ważniejszych elementów.

Studenci geografii turyzmu i hotelarstwa (w poprzednich latach także studenci geografii) podczas ćwiczeń mieli możliwość poznania jednego z najsłynniejszych miast Rosji - Sankt Petersburga, a także warunków funkcjonowania i organizowania turystyki w tym kraju. Istotnym elementem ćwiczeń była inwentaryzacja turystyczna głównej ulicy tego miasta, czyli Newskiego Prospektu. Badania inwentaryzacyjne były kontynuacja prac zapoczątkowanych przez dr J. Latosińską - opiekuna grupy studentów podczas ćwiczeń w $2005 \mathrm{r}$.

\section{PROGRAM ĆWICZEŃ}

Program pobytu przygotowany dla naszej grupy przez stronę rosyjską był bardzo bogaty (tab. I).

\section{INTRODUCTION}

Between $3^{\text {rd }}$ and $15^{\text {th }}$ July 2006, following an agreement between the University of Łódź and the 'Russian State Hydro-meteorological University' in St Petersburg, Polish $3^{\text {rd }}$ year students of tourism and hotel management took part in fieldwork training in the Russian Federation. The group consisted of five students and two supervisors from the Department of Urban and Tourism Geography. This is the fourth fieldwork training session as cooperation between the two universities started in 2002, and the annual exchange is one of its most important elements.

The students (in previous years geography department students too) had an opportunity to get to know St Petersburg, one of the most famous cities in Russia, as well as the conditions in which tourism functions and is organized there. An important element of the training was a tourism inventory of the main street of the city - Nevsky Prospekt, a continuation of work initiated by Dr J. Latosinska, the group supervisor in 2005.

\section{FIELDWORK TRAINING SYLLABUS}

The syllabus prepared by the Russians for our group was very extensive (table I). 
T a b e la I. Program ćwiczeń terenowych w Sankt Petersburgu w $2006 \mathrm{r}$.

\begin{tabular}{|c|c|}
\hline 3.07 . & $\begin{array}{l}\text { Oficjalne powitanie grupy studentów i pracowników Ut przez } \\
\text { dziekana Wydziału Ekologii i Fizyki Środowiska Przyrodnicze- } \\
\text { go Uniwersytetu w Petersburgu, Annę Lwowna Skoblikowa. } \\
\text { W godzinach popołudniowych autokarowa wycieczka po histo- } \\
\text { rycznym centrum miasta. }\end{array}$ \\
\hline 4.07. & $\begin{array}{l}\text { Referat rosyjskich studentów na temat historii powstania St } \\
\text { Petersburga, zwiedzanie Twierdzy Pietropawłowskiej, soboru } \\
\text { sw. sw. Piotra i Pawła. Po południu rejs tramwajem wodnym po } \\
\text { rzekach i kanałach miasta: Mojka, Fontanka, kanał Griboje- } \\
\text { dowa. }\end{array}$ \\
\hline 5.07 . & $\begin{array}{l}\text { Referat rosyjskich studentów o petersburskich muzeach, zwie- } \\
\text { dzanie Ermitażu i soboru Kazańskiego. }\end{array}$ \\
\hline 6.07. & $\begin{array}{l}\text { Poznawanie architektury i historii carskiego zespołu pałacowo- } \\
\text {-parkowego Peterhof. Piknik na nadbałtyckiej plaży nad Zatoka } \\
\text { Fińska, powrót do miasta droga wodna (wodolotem). }\end{array}$ \\
\hline 7.07. & $\begin{array}{l}\text { Zwiedzanie soboru św. Izaaka, podziwianie panoramy miasta } \\
\text { z kopuly soboru. Referat rosyjskich studentów o pomnikach } \\
\text { w St Petersburgu. Zwiedzanie miasta: pomnik cara Mikołaja I, } \\
\text { pomnik Miedzianego Jeżdżca (cara Piotra I), budynek Admira- } \\
\text { liciji. Nocny spacer po mieście. }\end{array}$ \\
\hline $\begin{array}{l}8-9 . \\
07 .\end{array}$ & $\begin{array}{l}\text { Podróż podmiejską koleją do Dajmiszcze, stacji terenowej Pań- } \\
\text { stwowego Hydro-Meteorologicznego Uniwersytetu. Dzień pierw- } \\
\text { szy - poznanie dydaktycznej bazy petersburskiej uczelni (ogró- } \\
\text { dek meteorologiczny, astronomiczny, odkrywki glebowe) i walo- } \\
\text { rów przyrodniczych najbliższej okolicy (wiejskie parki, jaskinie, } \\
\text { żródła). Wysłuchanie koncertu pieśni rosyjskiej, wieczorem ka- } \\
\text { piel w tradycyjnej rosyjskiej bani. Dzień drugi - wycieczka auto- } \\
\text { karowa szlakiem miejsc związanych z A. Puszkinem i powrót do } \\
\text { Petersburga. }\end{array}$ \\
\hline 10.07. & $\begin{array}{l}\text { Wizyta w Muzeum Osobliwości - Kunstkamera. Zwiedzanie } \\
\text { ogrodów i parków miejskich, Letni Ogród i Pole Marsowe. In- } \\
\text { wentaryzacja turystyczna Newskiego Prospektu. }\end{array}$ \\
\hline 11.07. & $\begin{array}{l}\text { Wizyta w oceanarium. Referat rosyjskich studentów nt. peter- } \\
\text { sburskich fontann. Zwiedzanie miasta (plac Moskiewski, pomnik } \\
\text { Lenina, pomnik Obrońców Leningradu). Spacer nabrzeżem Mój- } \\
\text { ki - Mała Holandia. Inwentaryzacja turystyczna Newskiego Pro- } \\
\text { spekłu. }\end{array}$ \\
\hline 12.07 . & $\begin{array}{l}\text { Wyjazd do Carskiego Sioła, zwiedzanie podmiejskiej rezydencji } \\
\text { carów. Spektakl baletowy w Teatrze Maryjskim. }\end{array}$ \\
\hline 13.07. & $\begin{array}{l}\text { Zwiedzanie Ławry Aleksandra Newskiego (klasztor i historyczne } \\
\text { nekropolie). } \\
\text { Oficjalne zakończenie ćwiczeń, wizyta u rektora Uniwersytetu, } \\
\text { wykład dziekan Anny Lwownej Skoblikowej, podsumowanie po- } \\
\text { bytu i wydanie certyfikatów. }\end{array}$ \\
\hline
\end{tabular}

Ż r ó d ło: Opracowanie na podstawie programu przygotowanego przez stronę rosyjską.

Uwzględniono w nim zwiedzanie różnorodnych obiektów zarówno tych najsłynniejszych, stanowiących swoisty kanon turysty odwiedzającego to miasto, jak i mniej znanych, ale równie wartych zobaczenia. Dzięki temu polscy studenci odwiedzili wiele świątyń, muzeów, zespolów parkowo-pałacowych (także podmiejskich carskich rezydencji), cmentarzy, parków, oglądali place $z$ pomnikami, fontanny, teatry. $W$ jednym $z$ nich - Teatrze Maryjskim - mieli okazję uczestniczyć w wydarzeniu, jakim był spektakl baletowy z udziałem wybitnych rosyjskich artystów. Z obiektów nowoczesnych wymienić należy nowo otwarte oceanarium i centra handlowe. W poznawaniu Pe-
T a b I e I. Syllabus of the fieldwork training in St Petersburg

\begin{tabular}{|c|c|}
\hline 3.07. & $\begin{array}{l}\text { The official welcoming of the University of Łódż students and } \\
\text { supervisors by the Dean of the Physical Environment and } \\
\text { Ecology Department, Anna Lvovna Skoblikova. In the afternoon } \\
\text { a coach trip to the historical city centre. }\end{array}$ \\
\hline 4.07 & $\begin{array}{l}\text { Russian students' presentation of the origins of St Petersburg, } \\
\text { visiting the Peter and Paul Fortress and Peter and Paul } \\
\text { Cathedral. In the afternoon - a cruise on the city's rivers and } \\
\text { canals: Moika, Fontanka, Gribojedova Canal. }\end{array}$ \\
\hline 5.07 . & $\begin{array}{l}\text { Russian students' presentation of St Petersburg museums and } \\
\text { visiting the Hermitage and Kazan Cathedral. }\end{array}$ \\
\hline 6.07 & $\begin{array}{l}\text { he architecture and history of the Peterhof } \\
\text { complex. A picnic on a Gulf of Finland beach, } \\
\text { y boat. }\end{array}$ \\
\hline 7.07 & $\begin{array}{l}\text { Visiting St Isaac's Cathedral, admiring the city panorama from } \\
\text { the dome. Russian students' presentation of monuments in St } \\
\text { Petersburg. Sightseeing: the monument of Tsar Nicholas I, the } \\
\text { Bronze Horseman (Tsar Peter I), the Admiralty building. A night } \\
\text { walk in the city. }\end{array}$ \\
\hline $\begin{array}{l}8-9 . \\
07 .\end{array}$ & $\begin{array}{l}\text { A train trip to Dajmiszcze, a Hydro-Meteorological University } \\
\text { centre. Day one - learning about the basic teaching (meteoro- } \\
\text { logical and astronomical gardens, soil profiles), discovering the } \\
\text { natural assets of the vicinity (country parks, caves, springs). } \\
\text { Listening to a Russian song concert, in the evening - a bath in } \\
\text { a traditional Russian bath. Day two - a coach trip to places } \\
\text { connected to Alexander Pushkin and the return to St Peters- } \\
\text { burg. }\end{array}$ \\
\hline 10.07 & $\begin{array}{l}\text { osities' (Kunstkammer). Visiting city } \\
\text { mmer Gardens and Field of Mars. } \\
\text { Prospekt. }\end{array}$ \\
\hline 11.07. & $\begin{array}{l}\text { A visit to the oceanarium. Russian students' presentation of the } \\
\text { fountains in St Petersburg. Sightseeing (Moscow Square, the } \\
\text { statues of Lenin and the Leningrad Defenders). A walk on the } \\
\text { Moika banks - New Holland. Tourism inventory of Nevsky } \\
\text { Prospekt. }\end{array}$ \\
\hline 12.07. & $\begin{array}{l}\text { A trip to Tsarskoe Selo to visit the tsarist palace. A ballet } \\
\text { spectacle at the Mariinsky Theatre. }\end{array}$ \\
\hline 13.07. & $\begin{array}{l}\text { Visiting Alexander Nevsky Monastery (cloister and historic } \\
\text { cemeteries). } \\
\text { Official closing of the fieldwork training, meeting with the Rector, } \\
\text { a lecture by Anna Lvovna Skoblikova, summary of the stay and } \\
\text { receiving certificates. }\end{array}$ \\
\hline
\end{tabular}

S o u r c e: Based on the syllabus prepared by the Russian hosts.

It comprised visits to a variety of places, both the most famous on the city tourism 'canon', and those less well known but also worth seeing. Polish students visited a number of shrines, museums, palace and park complexes (including the tsarist residences outside the city), cemeteries and parks, and they saw squares with statues, fountains, and theatres. In one of them, the Mariinsky Theatre, they watched a ballet with distinguished Russian dancers performing. Among the modern buildings the newly opened oceanarium and shopping centres should be mentioned. The 
tersburga grupie polskiej zawsze towarzyszyli studenci rosyjscy. Wygłaszane przez nich referaty pozwoliły poszerzyć wiedzę oraz zdobyć praktyczne wiadomości. Ponadto organizowali oni nasz czas wolny i wskazywali na miejsca kultury i rozrywki popularne wśród mieszkańców Petersburga.

Podczas weekendu spędzonego poza miastem, w uniwersyteckiej bazie terenowej (w Dajmiszcze), polscy studenci mieli okazję poznania przyrodniczych, kulturowych oraz historycznych walorów zachodniej części obwodu leningradzkiego. Jednocześnie wyjazd ten stworzył możliwość zapoznania się ze sposobem i warunkami odbywania praktyk przez studentów rosyjskich.

W ostatnim dniu pobytu grupa została przyjęta przez rektora uczelni prof. Lwa Karlina. Na spotkaniu, przebiegającym w bardzo przyjaznej atmosferze, studenci dzielili się wrażeniami, jakie towarzyszyły im podczas odbywania praktyk. Merytorycznym podsumowaniem całości ćwiczeń był wykład dziekan Anny Lwownej Skoblikowej nt. turystycznego potencjału St. Petersburga oraz możliwości i barier rozwoju turystyki w tym mieście. Wykład uświadomił nam, że nasze indywidualne odczucia i spostrzeżenia w zakresie turystyki są zbieżne z diagnozą rosyjskich specjalistów. Na zakończenie otrzymaliśmy (wraz z małymi upominkami) certyfikaty poświadczające odbycie praktyki terenowej.

\section{NEWSKI PROSPEKT - INWENTARYZACJA OBIEKTÓW TURYSTYCZNYCH I PARATURYSTYCZNYCH}

Newski Prospekt jest główną ulicą Sankt Petersburga, mierzącą 4,5 km długości. Rozpoczyna się przy pałacu Admiralicji, a kończy przy Ławrze Aleksandra Newskiego. Prospekt został wytyczony w pierwszych latach budowy miasta przez francuskiego architekta Alexandre'a Jeana Baptista Le Blonda, na zlecenie cara Piotra I (RICHMOND i in., 2005). Początkowo pełnił funkcję drogi na Nowogród, z czasem stał się reprezentacyjną aleją, zwłaszcza na odcinku od pałacu Admiralicji po rzekę Fontankę (kamienice usytuowane $\mathrm{w}$ dalszej części są mniej reprezentacyjne). Obecnie znajduje się tu wiele sklepów, głównie luksusowych, kilka bardzo drogich hoteli oraz restauracji, a także różnorodne budowle o zabytkowym charakterze, m.in. Sobór Kazański, pałac Woroncowa, pomnik Katarzyny II.
Polish students were accompanied by Russian students who made presentations thus providing practical information. They also organized our free time and pointed out the cultural and entertainment centres popular among the inhabitants of St Petersburg.

During the weekend spent outside the city in a university centre (in Dajmiszcze), the Polish students had an opportunity to see the natural, cultural and historical assets of the western part of the 'Leningrad Region'. At the same time they experienced Russian student fieldwork training.

On the last day the group were seen by the Rector of the University, Prof. Lew Karlin in a very friendly atmosphere and the students shared their impressions. Anna Lvovna Skoblikova, the Dean, gave a lecture summing up the whole of the training visit on the topic of the tourism potential of St Petersburg, as well as the prospects for tourism development in this city. The lecture made us aware that our individual impressions and observations as regarded tourism coincided with the prognosis made by the Russian specialists. At the end we received field-work training certificates, together with small gifts.

\section{NEVSKY PROSPEKT - INVENTORY OF TOURISM AND QUASI-TOURISM SITES}

Nevsky Prospekt is the main street of St Petersburg, $4.5 \mathrm{~km}$ in length, starting at the Admiralty Palace and finishing at the Alexander Nevsky monastery. It was commissioned by Tsar Peter I and laid out in the first years of the construction of the city by a French architect Jean-Baptiste Alexandre Le Blond (RICHMOND et al., 2005). At first it was the road to Novgorod but with time becoming an elegant avenue, especially in its section between the Admiralty Palace and the Fontanka river (the houses built further on are less spectacular). At present there are a lot of expensive shops, several luxurious hotels and restaurants, as well as a variety of historical monuments, such as 
T a b e l a II. Wyniki inwentaryzacji zagospodarowania turystycznego Newskiego Prospektu w Sankt Petersburgu z podziałem na kategorie obiektów

\begin{tabular}{|c|c|c|c|c|c|}
\hline \multirow[b]{2}{*}{ Kategorie główne } & \multicolumn{3}{|c|}{ Podkategorie } & \multirow{2}{*}{$\begin{array}{l}\text { Liczba } \\
\text { obiektów }\end{array}$} & \multirow{2}{*}{$\begin{array}{c}\text { Udzial } \\
\text { procentowy }\end{array}$} \\
\hline & wyszczególnienie & $\begin{array}{c}\text { liczba } \\
\text { obiektów }\end{array}$ & $\begin{array}{c}\text { udzial } \\
\text { procentowy }\end{array}$ & & \\
\hline $\begin{array}{l}\text { Sklepy } \\
\text { - w tym: }\end{array}$ & $\begin{array}{l}\text { ogółem } \\
\text { - spożywcze } \\
\text { - odzieżowe i obuwnicze } \\
\text { - z pamiątkami } \\
\text { - księgarnie i muzyczne } \\
\text {-inne }\end{array}$ & $\begin{array}{r}7 \\
49 \\
5 \\
12 \\
52 \\
\end{array}$ & $\begin{array}{r}5,6 \\
39,2 \\
4,0 \\
9,6 \\
41,6 \\
\end{array}$ & 125 & 35,8 \\
\hline $\begin{array}{l}\text { Obiekty gastronomiczne } \\
\text { - w tym: }\end{array}$ & $\begin{array}{l}\text { ogółem } \\
\text { - kawiamie } \\
\text { - bary } \\
\text { - restauracje } \\
\text { - inne }\end{array}$ & $\begin{array}{r}18 \\
22 \\
12 \\
7 \\
\end{array}$ & $\begin{array}{l}30,5 \\
37,3 \\
20,3 \\
11,9\end{array}$ & 59 & 16,9 \\
\hline Hotele & & & & 9 & 2,6 \\
\hline Banki i kantory & & & & 17 & 4,8 \\
\hline Biura turystyczne & & & & 18 & 5,2 \\
\hline Muzea, & & & & 5 & 1,4 \\
\hline Punkty sprzedaży biletów & & & & 8 & 2,3 \\
\hline Kina, teatry, filharmonie & & & & 11 & 3,2 \\
\hline Obiekty rozrywkowe - kluby, kasyna & & & & 3 & 0,9 \\
\hline Obiekty sakralne & & & & 2 & 0,6 \\
\hline $\begin{array}{l}\text { Inne } \\
\qquad-w \text { tym: }\end{array}$ & $\begin{array}{l}\text { ogółem } \\
\text { - budki telefoniczne, poczta } \\
\text { - bankomaty } \\
\text { - skrzynki pocztowe } \\
\text { - stacje metra } \\
\text { - salony piękności } \\
\text { - kawiarenki internetowe } \\
\text { - pozostałe }\end{array}$ & $\begin{array}{r}38 \\
5 \\
6 \\
4 \\
3 \\
3 \\
33 \\
\end{array}$ & $\begin{array}{r}41,3 \\
5,4 \\
6,5 \\
4,3 \\
3,3 \\
3,3 \\
35,9 \\
\end{array}$ & 92 & 26,2 \\
\hline Z r ód ło: Opracowanie własne. & & & Suma & 349 & 100,0 \\
\hline
\end{tabular}

T a b I I II. Inventory of the tourism infrastructure of Nevsky Prospekt by category

\begin{tabular}{|c|c|c|c|c|c|}
\hline \multirow[b]{2}{*}{ Main categories } & \multicolumn{3}{|c|}{ Sub-categories } & \multirow{2}{*}{$\begin{array}{l}\text { No of } \\
\text { outlets }\end{array}$} & \multirow[b]{2}{*}{$\%$} \\
\hline & specification & $\begin{array}{c}\text { no of } \\
\text { outlets }\end{array}$ & $\%$ & & \\
\hline $\begin{array}{l}\text { Shops } \\
\text { - including: }\end{array}$ & $\begin{array}{l}\text { total } \\
\text { - food shops } \\
\text { - clothes and shoe shops } \\
\text { - souvenir shops } \\
\text { - book and music shops } \\
\text { - other }\end{array}$ & $\begin{array}{r}7 \\
49 \\
5 \\
12 \\
52 \\
\end{array}$ & $\begin{array}{r}5.6 \\
39.2 \\
4.0 \\
9.6 \\
41.6 \\
\end{array}$ & 125 & 35.8 \\
\hline $\begin{array}{l}\text { Gastronomic outlets } \\
\text { - including: }\end{array}$ & $\begin{array}{l}\text { total } \\
\text { - cafes } \\
\text { - bars } \\
\text { - restaurants } \\
\text { - other }\end{array}$ & $\begin{array}{r}18 \\
22 \\
12 \\
7\end{array}$ & $\begin{array}{l}30.5 \\
37.3 \\
20.3 \\
11.9\end{array}$ & 59 & 16.9 \\
\hline Hotels & & & & 9 & 2.6 \\
\hline Banks and bureaux de change & & & & 17 & 4.8 \\
\hline Tourist agencies & & & & 18 & 5.2 \\
\hline Museums & & & & 5 & 1.4 \\
\hline Ticket offices & & & & 8 & 2.3 \\
\hline Cinemas, theatres, concert halls & & & & 11 & 3.2 \\
\hline Entertainment facilities - clubs, casinos & & & & 3 & 0.9 \\
\hline Churches & & & & 2 & 0.6 \\
\hline $\begin{array}{l}\text { Others } \\
\text { - including: }\end{array}$ & $\begin{array}{l}\text { total } \\
\text { - telephone boxes, post office } \\
\text { - cash dispensers } \\
\text { - post boxes } \\
\text { - underground stations } \\
\text { - beauty parlours } \\
\text { - internet cafes } \\
\text { - other }\end{array}$ & $\begin{array}{r}38 \\
5 \\
6 \\
4 \\
3 \\
3 \\
33\end{array}$ & $\begin{array}{r}41.3 \\
5.4 \\
6.5 \\
4.3 \\
3.3 \\
3.3 \\
35.9 \\
\end{array}$ & 92 & 26.2 \\
\hline Source: Author. & & & Suma & 349 & 100.0 \\
\hline
\end{tabular}


Badaniem inwentaryzacyjnym przeprowadzonym podczas ćwiczeń terenowych objęto odcinek od Admiralicji (nr 1) do placu Powstania (nr 118), na którym skupia się większa część ruchu turystycznego. Celem inwentaryzacji było dokonanie spisu elementów infrastruktury służącej turystom, usytuowanych $w$ bezpośrednim dostępie z ulicy, tj. na poziomie parteru kamienic oraz innych obiektów. Świadomie zrezygnowano $\mathrm{z}$ przeprowadzenia inwentaryzacji na wyższych kondygnacjach oraz w podwórzach czy przecznicach, ze względu na dużą liczbę obiektów i zbyt małą liczbę osób inwentaryzujących. Szczegółowym badaniem objęto 349 obiektów, które pogrupowano w 11 kategorii (tab. II). Kategorie te obejmują 1) sklepy, do których zaliczono: spożywcze, odzieżowe, obuwnicze, z pamiątkami, księgarnie, muzyczne i inne; 2) obiekty gastronomiczne, czyli kawiarnie, bary, restauracje i inne 3) hotele; 4) banki i kantory; 5) biura turystyczne; 6) muzea; 7) kina, teatry i filharmonie; 8) punkty sprzedaży biletów m.in. teatralnych, lotniczych; 9) obiekty rozrywkowe, w tym kluby i kasyna; 10) obiekty sakralne. Do ostatniej kategorii ,inne” zaliczono: budki telefoniczne, pocztę, bankomaty, skrzynki pocztowe, stację metro, a także salony piękności, kawiarenki internetowe i pozostałe obiekty.

$\mathrm{Z}$ badań wynika, że na badanym odcinku ulicy dominują obiekty handlowe (125), przy czym zdecydowanie najwięcej jest wśród nich sklepów odzieżowych i obuwniczych (49), często należących do znanych firm światowych projektantów. Im bliżej placu Powstania, tym sklepy są mniejsze pod względem zajmowanej powierzchni i bardziej zróżnicowane asortymentowo. Stosunkowo niewiele, jak na główną ulicę, jest na Newskim Prospekcie sklepów z pamiątkami (tylko pięć) oraz spożywczych (siedem), które koncentrują się głównie w pobliżu stacji metra. W zakresie zakupu żywności pewną rekompensatą dla turystów w sezonie letnim mogą być liczne ruchome punkty tzw. małej gastronomii, czyli budki z hamburgerami oraz wózki lodówki z napojami, lodami czy słodyczami. Poza tym spory jest wybór stałych obiektów gastronomicznych, których na badanym fragmencie ulicy jest aż 59, w tym 12 restauracji oferujących najróżniejsze kuchnie, np. regionalne świata, 18 kawiarń i 22 różnego typu bary.

Oferta noclegowa jest mało zróżnicowana, przy Newskim Prospekcie bezpośrednio (w świetle kryteriów inwentaryzacji) ulokowanych jest tylko siedem takich obiektów. Są to hotele o wysokim i bardzo wysokim standardzie (4-5 gwiazdek), np. Hotel Anabelt, Hotel Newski Prospekt. Ponadto stosunkowo dużo jest biur turystycznych (18), których
Kazan Cathedral, Voroncov Palace, and the statue of Catherine II.

The section between the Admiralty (No 1) and Ploshchad Vosstaniya (No 118), where most tourism activity is found, was investigated. The aim was to list all elements of tourism infrastructure within direct reach of the street, i.e. at ground floor level. Cataloguing the higher floors, yards or side streets was abandoned intentionally due to the large number of buildings and lack of people to do the task. The detailed examination comprised 349 buildings grouped into eleven categories (table II): 1) shops including food shops, clothes shops, shoe shops, souvenir shops, bookshops, music shops, etc., 2) catering outlets i.e. cafes, bars, restaurants, etc., 3) hotels; 4) banks and bureaux de change; 5) tourist agencies; 6) museums; 7) cinemas, theatres and concert halls; 8) ticket offices (selling theatre and plane tickets); 9) entertainment facilities - including clubs and casinos; and 10) churches. The last category (11) 'other' - included telephone boxes, a post office, cash dispensers, post boxes, an underground station, as well as beauty parlours, internet cafes, etc.

The study shows that shops predominate in this section of the street (125), most of them being clothes and shoe shops (49) often of world-famous designer brands. The closer to Ploshchad Vosstaniya (Insurrection Square), the smaller the shops and the more varied the stock. There are relatively few souvenir shops (only 5) and food shops (7) - which can be found mainly around the underground station. For sources of food, street kiosks are a certain compensation for tourists in summer with hamburgers, cold drinks, ice-creams and sweets. Apart from these there is quite a wide choice of restaurants (12) offering different cuisines, cafes (18) and bars (22).

Accommodation is not varied, there are only seven hotels directly on Neusky Prospect, all of them of high or very high standard (4-5 stars), e.g. Anabelt Hotel or the Neusky Prospekt Hotel. There 
większość znajduje się na odcinku od Prospektu Władymirskiego do placu Powstania, a także siedzib związków (o ich obecności świadczą liczne tablice umieszczone na fasadach budynków, np. Dom Dziennikarza).

Przy ulicy omawianego jej fragmentu znajdują się dwa teatry, kilka muzeów i wiele kin. Zdumiewająca jest liczba tych ostatnich (ponad 10), które często są zlokalizowane bardzo blisko siebie, np. między $\mathrm{nr} 72$ a 86 występują aż cztery. Występują tu liczne punkty pośredniczące $\mathrm{w}$ sprzedaży biletów teatralnych, lotniczych albo na turystyczne wycieczki po mieście, ewentualnie okolicy, np. do dawnych podmiejskich rezydencji carów.

Lokalną specyfiką Newskiego Prospektu w sezonie letnim są tzw. ,naganiacze”, dość głośno informujący o możliwościach uczestnictwa turystów w wycieczkach autokarowych bądź „białą flotą” po rzekach i kanałach miasta. Taką formę ,punktów handlowych" silnie ze sobą konkurujących (często poprzez wzajemne przekrzykiwanie się i zagłuszanie) trudno uwzględnić w materiale inwentaryzacyjnym, ale warto o niej wspomnieć, jako o zjawisku bardzo charakterystycznym dla tej ulicy. Do innych osobliwych obiektów shuzących nie tylko turystom, ale are a relatively large number of tourist agencies (18), most of which can be found in the section between Vladimirskaya Prospekt and Ploshchad Vosstaniya, and also the headquarters of various organizations marked with plaques on the facades (e.g. Journalist's House).

In this section there are two theatres, several museums and many cinemas. The number of the latter is truly amazing (over ten) and they are often very close to each other, e.g. between number 72 and 86 there are four. There are also many ticket offices selling theatre, plane or city tour tickets or tickets for tours of the area, e.g. to former tsarist residences.

A local 'speciality' of Neusky Prospekt in the summer season are the touts who loudly advertise coach tours or cruises on the rivers and city canals. This form of commercial activity is difficult to inventorise, but worth mentioning as very characteristic of the street. Another peculiarity which serves both tourists and city inhabitants
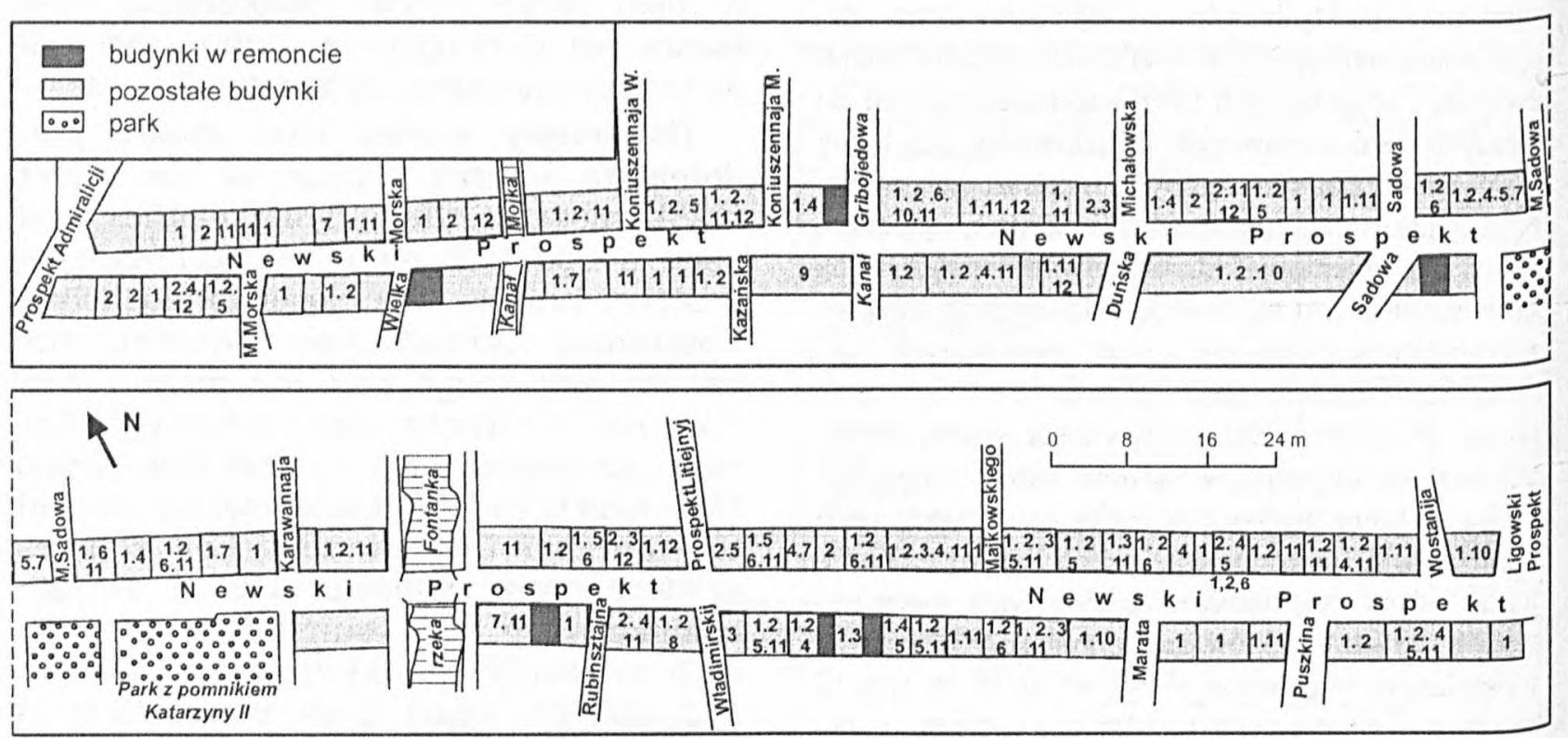

1-sklepy, 2 - obiekty gastronomiczne, 3 - hotele, 4 - banki i kantory, 5 - biura turystyczne, 6 - kina, teatry, filharmonie, 7 - muzea, 8 - obiekty rozrywkowe, 9 - obiekty sakralne, 10 - stacje metra, 11 - budki telefoniczne, 12 - punkty sprzedaży biletów lotniczych, kolejowych, do teatru, na wycieczki

Rys. 1. Obiekty turystyczne i paraturystyczne na Newskim Prospekcie w Sankt Petersburgu - wyniki inwentaryzacji w 2006 r.

1 - shops, 2 - gastronomic outlets, 3 - hotels, 4 - banks and bureaux de change, 5 - tourist agencies, 6 - cinemas, theatres, concert halls, 7 - museums, 8 -places of entertainment, 9 - churches, 10 - underground stations 11 - telephone boxes, 12 - ticket offices selling flight, rail, theatre and excursion tickets 
i mieszkańcom miasta należy również zaliczyć tzw. „wołacze milicji”, czyli urządzenia przypominające domofon, które w razie potrzeby ułatwiają szybki kontakt $\mathrm{z}$ najbliższym komisariatem.

$\mathrm{Na}$ badanym odcinku stwierdzono dość skromną liczbę bankomatów (pięć) i kawiarenek internetowych (trzy) oraz obiektów rozrywkowych, jak dyskoteki, puby, kasyna (tylko trzy). Wydaje się, iż jak na charakter Newskiego Prospektu i liczbę przebywających tam turystów jest to oferta bardzo znikoma.

Rys. 1. przedstawia rozmieszczenie analizowanych kategorii infrastruktury wzdhuż badanego fragmentu ulicy, przy czym na planie uwzględniono wyłącznie fakt występowania danej kategorii w konkretnej kamienicy bądź obiekcie (bez określenia liczby). Analizując rysunek można zauważyć w miarę równomierne występowanie obiektów handlowych (tj. różnego rodzaju sklepów). Pewne ich nasilenie dostrzec można przy stacjach metra. Hotele koncentrują się między przecznicami Władimirski Prospekt i ulicą Marata, gdzie na odcinku $420 \mathrm{~m}$ znajdują się trzy. Regularnie rozmieszczone są budki telefoniczne, których jest ok. 40. Na badanym odcinku znajdują się cztery stacje metra, choć także po Newskim Prospekcie kursują miejskie autobusy.

$\mathrm{Na}$ podstawie przeprowadzonej inwentaryzacji można też zaobserwować, że północna strona ulicy jest bogatsza w elementy infrastruktury shuzace turystom. Po przeciwnej stronie jest natomiast więcej gmachów publicznych, takich jak biblioteka czy siedziba korporacji, oraz otwartych przestrzeni, np. park. Poza tym kilka kamienic po południowej stronie ulicy było w remoncie (należy dodać, iż nie wpływało to negatywnie na percepcję ulicy, ponieważ prace budowlane zasłonięte były płachtami imitującymi oryginalne elewacje remontowanych kamienic).

Podsumowując przeprowadzoną analizę zabudowy Newskiego Prospektu należy podkreślić, że mimo pewnych ograniczeń związanych z organizacją inwentaryzacji, zebrany materiał pozwolił na pokazanie specyfiki zagospodarowania turystycznego reprezentacyjnej ulicy Sankt Petersburga. Handlowy charakter prospektu szczególnie podkreślają ekskluzywne sklepy przeznaczone dla zamożnych turystów. Dobrze rozwinięta i urozmaicona baza gastronomiczna pozwala zaspokoić potrzeby i upodobania różnych grup klientów zarówno mniej, jak i bardziej wymagających. Niepowtarzalny koloryt ulicy, mozaika barw i zapachów, odrestaurowane zabytki czynią z niej z jednej strony luksusową i „europejską", a z drugiej strony na wskroś rosyjską arterię miasta. are the police phones - devices similar to intercoms which are used when there is a need for quick police intervention.

In this section there are some cash dispensers (5), internet cafes (3) and entertainment facilities such as discos, pubs or casinos (only 3 ).

Fig. 1 presents the distribution of tourism infrastructure (the plan shows only that a given category occurs in a given building - not how many). Shops are distributed quite evenly, with a slight concentration around underground stations. Most hotels are between Vladimirskaya Prospekt and Marata Street where there are three within a distance of 420 metres. Phone boxes (about 40) are distributed evenly and there are four underground stations, apart from regular bus services.

It was also discovered that the northern side of the street is richer in tourism infrastructure. On the other side there are more public buildings such as libraries or business headquarters, as well as open spaces, e.g. parks. Besides, several buildings on the southern side were being restored (this did not spoil the perception of the street, as the construction sites were shielded by sheets imitating the original elevations).

To sum up, despite several limitations regarding the inventory method, the collected material clearly shows the special character of the tourism infrastructure in the most elegant street of St Petersburg, seen both in quantity and variety. The commercial character of the Neusky Prospekt is strongly accentuated by exclusive shops for welloff tourists. A well-developed and varied catering system satisfies the needs and tastes of different groups of customers, both more and less demanding. The exceptional atmosphere of the street, a mosaic of colours and smells and renovated monuments, make it a luxurious European, yet at the same time very Russian, artery of the city. 


\section{PERCEPCJA SANKT PETERSBURGA}

Wizyta w Sankt Petersburgu pozostawiła po sobie niezapomniane wrażenia towarzyszące od momentu rozpoczęcia wyprawy, aż po jej zakończenie. Dla studentów - przyszłych organizatorów turystyki - pewnym przeżyciem byla ponadtrzydziestogodzinna podróż pociągiem (Lódź-Warszawa-Petersburg), a nawet zabieg związany ze zmianą rozstawu szyn kolejowych po przekroczeniu granicy z Białorusią. Długa podróż umożliwiła przeprowadzenie ciekawych obserwacji poczynionych zarówno w pociągu, jak i za oknami jego wagonów. Pierwsze "pięć minut” spędzone w petersburskiej metropolii ukazały obraz dobrego funkcjonowania przestrzeni publicznej oraz sprawiały wrażenie porządku w mieście. Dłuższy pobyt pokazał, że jest jednak inaczej.

Szkieletem komunikacyjnym pięciomilionowej metropolii są cztery linie metra. Jego stacje - należące do najgłębszych na świecie, niektóre o bardzo efektownym wystroju - stanowią dużą atrakcję turystyczna. Jednak panująca $w$ nich atmosfera pośpiechu, tłok i niemożność uzyskania informacji w językach obcych, raczej wypiera turystów do transportu naziemnego. Jedną $\mathrm{z}$ form takiego transportu jest tramwaj retro. Obwozi pasażerów po północnej części miasta, nie docierając niestety na obszary o największej atrakcyjności turystycznej. Korzystanie $\mathrm{z}$ innych form transportu miejskiego, jak: tramwaje miejskie, trolejbusy, autobusy oraz tzw. „marszrutki” (prywatne autobusy), jest dość skomplikowane dla obcokrajowca. Na przystankach nie ma rozkładów jazdy, a kierowcy zatrzymują się tam, gdzie im wskażą pasażerowie.

Należy pamiętać, że jadąc do Rosji powinno się znać język tego kraju, w przeciwnym razie turystę może spotkać wiele niespodzianek Tablice informacyjne, cenniki usług, różne oferty itp. gdzieniegdzie tylko przethumaczone są na język angielski lub niemiecki. Brak znajomości języków obcych u Rosjan dotyczy niestety także osób pracujących przy obsłudze ruchu turystycznego, co bardzo utrudnia sprawne poruszanie się turystów po mieście.

Mnogość zabytków Petersburga sprawia natomiast, że będąc tam nawet dwa tygodnie, nie zdąża się wszystkiego zobaczyć, a wybór obiektów do zwiedzania jest bardzo trudny i często zależy od zasobów finansowych. Podstawowy „kanon turysty" niestety nie należy do tanich, zwłaszcza że ceny dla turystów zagranicznych (także w muzeach) są niemal zawsze znacznie wyższe (nawet 5-6 razy) niż ceny dla obywateli rosyjskich. Na pocie-

\section{PERCEPTIONS OF ST PETERSBURG}

The visit to St Petersburg was very impressive from the beginning to the end. The journey by train, which lasted over 30 hours (including the change of rail gauge), was quite an experience for the students as future tourism organisers and they were able to make many observations, both on the train and from its windows. The first 'five minutes' in St Petersburg gave an impression of an ordered and well functioning public space but the longer stay proved that the situation is slightly different.

The transportation network of the city, inhabited by five million people, is formed by four underground lines. The stations, some of them with a very attractive décor, are among the deepest in the world and a great tourist attraction. However, the hectic atmosphere, crowds and lack of information in foreign languages, push the tourists towards surface transport. One of these is the retro-tram which takes tourists to the northern part of the city but, regrettably, does not reach the areas which are most attractive from the tourist point of view. Using other means of city transport such as trams, trolleybuses, city buses and private buses is quite complicated for a foreigner. There are no schedules at bus or tram stops, and the driver stops the vehicle as indicated by the passengers.

It should be pointed out that whoever travels to Russia should know the language; otherwise they may find themselves in trouble. Information boards, price lists and advertisements are rarely translated into English or German. What is more, people working directly in tourism services are often unable to speak foreign languages.

Due to the great number of historical monuments in St Petersburg it is impossible to see all of them even if one has two weeks to do so. The choice is very difficult and often depends on financial resources as the basic tourist 'canon' is not cheap, especially as prices for foreign tourists (in museums too) are nearly always higher (even 5-6 times as much) than prices for Russian citizens. Fortunately, 
szenie pozostaje fakt, że studenci z międzynarodową legitymacją płacą z reguly połowę mniej.

Osobliwą atrakcją Petersburga są „białe noce" (trwające od polowy maja do polowy lipca), podczas których można m.in. obserwować na Newie otwieranie i zamykanie zwodzonych mostów. Podnoszone są w nocy, o ściśle wyznaczonych godzinach, umożliwiając wplynięcie w górę rzeki morskim statkom. Ten swoisty spektakl, otwarty dla wszystkich, darmowy, przyciąga thumy widzów.

W Petersburgu niezapomniane wrażenie wywierają liczne, o ciekawej architekturze fontanny, szczególnie zaś jedna z nich - ogromna, zainstalowana na Newie, która wyrzucała wodę w rytm głośno granej muzyki klasycznej. Atrakcja ta została celowo uruchomiona na czas zjazdu (15-17 lipca) przedstawicieli najbogatszych państw świata i Rosji, popularnie zwanego spotkaniem grupy G8. Całe miasto zostało w tym czasie wyraźnie podporządkowane temu wydarzeniu - kamienice $\mathrm{z}$ szarych stawały się kolorowe, a słynne zabytki w kilka dni odzyskiwały blask.

Petersburg warto obejrzeć z pokładu statków płynących po rzekach i kanałach, których duża liczba dała miastu przydomek „Wenecji Pólnocy”. Jest to nie tylko przyjemna odmiana w sposobie zwiedzania, ale też doskonała możliwość podziwiania $\mathrm{z}$ zupełnie innej perspektywy klasycystycznych, secesyjnych i eklektycznych kamienic mieszczańskich, pałaców, bogato zdobionych mostów, pomników, a także obserwowania samych mieszkańców.

Jak w każdym mieście turystycznym, tak i w Petersburgu, na każdym kroku oferowane są pamiątki. Wśród nich najbardziej charakterystyczne to: matrioszki, drewniane oraz pluszowe zabawki, pamiątki przypominające czasy Związku Radzieckiego (np. flagi, ordery, medale), ale także fotografie rodziny carskiej, jaja à la Faberge, wełniane chustki, składanki z pocztówkami, a nawet puszkowane powietrze.

Będąc w Petersburgu, tak jak chyba w każdej podróży, nie można tylko oglądać. Trzeba spróbować choć na chwilę „wtopić” się w to miejsce, np. założyć okrycie na głowę (dotyczy kobiet) i iść na mszę do cerkwi, by zachwycić się śpiewem wiernych, skręcić w boczną uliczkę i zajrzeć w bramę kamienicy, aby poczuć atmosferę codziennego życia mieszkańców, pójść na miejski cmentarz, kupić bilet od konduktora $w$ trolejbusie. Takie $\mathrm{i}$ inne przeżycia pomogły nam prawdziwie „poczuć” Petersburg i odnaleźć w tym najbardziej europejskim $\mathrm{z}$ rosyjskich miast, rosyjską duszę. students with an international student's card usually pay half price.

A particular attraction of St Petersburg are the 'white nights', when the opening and closing of the drawbridges on the River Neva can be seen, raised during the night at certain times, in order to let in seagoing vessels moving up the river. This spectacle, open to everybody free of charge, attracts crowds.

Numerous, beautiful fountains leave an unforgettable impression. One of them, an enormous fountain on the River Neva, ejected water to the rhythm of loud classical music. It was built for the convention of the representatives from the wealthiest countries and Russia, popularly known as the G8 group. The whole city was appropriately prepared for this event - grey tenement houses became colourful, and the famous monuments regained splendour within a few days.

St Petersburg is worth looking at from the boats floating on the rivers and canals, which gave the city its nickname of 'Venice of the North'. These are not only a pleasant detour from an ordinary visit, but also a fantastic opportunity to admire the classicistic, secessionist and eclectic tenement houses as well as the palaces, richly decorated bridges, statues and the inhabitants themselves, from a completely different perspective.

Like any tourist city, in St Petersburg you are offered souvenirs wherever you go. The most typical are the Russian dolls, wooden or plush toys, and not only reminders of the Soviet Union (e.g. flags, orders, medals) but also photographs of the tsar's family, imitations of Fabergé eggs, woollen headscarves, postcards, and even canned air.

Being in St Petersburg should not mean experiencing the visible only. You should, at least for a moment, melt into this place, e.g. cover your head with a scarf (women) and go to a mass at an Orthodox church in order to delight in the singing; or turn into a side street, look into the gates of a tenement house, go to a cemetery, buy a ticket from a trolleybus driver. Such and similar experiences helped us truly feel St Petersburg and find the 'Russian soul' in this most European of the Russian cities. 


\section{PODSUMOWANIE}

Współpraca nawiązana między Uniwersytetem Łódzkim i Rosyjskim Państwowym Hydrometeorologicznym Uniwersytetem w Sankt Petersburgu przynosi wiele pozytywnych efektów. Polscy studenci mieli możliwość nie tylko poznania tego wyjątkowego miasta, ale także dokonania licznych spostrzeżeń oraz zdobycia doświadczeń pozwalających łatwiej zrozumieć warunki i sposób funkcjonowania turystyki w Rosji. Wizyta u naszych rosyjskich partnerów to także poznanie ich wizji rozwoju miasta poprzez turystykę, cenne kontakty zagraniczne i inspiracje do dalszych badań. Być może obecni studenci, przyszli organizatorzy turystyki, stworzą kiedyś innym okazję przeżycia pełnej wrażeń podróży do miasta Piotra I.

\section{CONCLUSIONS}

The cooperation between the University of Łódź and the 'Russian State Hydrometeorological University' in St Petersburg has brought many positive results. Polish students had an opportunity not only to see this exceptional city, but also make a lot of observations and gain experience which lets them understand the conditions and system of tourism in Russia. Our Russian partners' vision of the city development through tourism was explained, valuable foreign contacts were started and it was an inspiration for further study. Perhaps today's students, prospective future tourism organisers, will organize an unforgettable journey to Peter I's city for others in the future.

\section{BIBLIOGRAFIA - BIBLIOGRAPHY}

Malek E., Stefanowicz-Maciszczek E., 2006, Petersburg - miasto białych nocy, Wyd. Bezdroża, Kraków.

RATAJSKI L., 1989, Metodyka kartografii społeczno-gospodarczej, PPWK, Warszawa.
Richmond S., Elloott M., Horton P. 1 in., 2005, Rosjaprzewodnik Pascala. Pascal, Bielsko-Biała.

St. Petersburg. Kartograficzieskyj atlas, 2004, RAH, Moskwa. 